\title{
Bentuk Penguatan Pendidikan Karakter pada Peserta Didik dengan Penerapan Reward dan Punishment
}

\author{
Karine Rizkita, Bagus Rachmad Saputra \\ ${ }^{1}$ Universitas Negeri Malang, ${ }^{2}$ Universitas Negeri Malang \\ * e-mail: karinerizkita2210@gmail.com
}

\begin{abstract}
The writing of this article aimed to (1) support the giving and punishment of students' learning motivation, (2) discuss indicators of students who get prizes and penalties. This research was conducted using a qualitative descriptive method to obtain facts in the field about the form of increasing character education in students with the application of gifts and penalties. Researchers conducted field studies and conducted interviews with and conducted documentation studies at SMP Negeri 1 Bojonegoro as a research location. The results of the research found by researchers at SMP Negeri 1 Bojonegoro are as follows: (1) the application of rewards and punishments to the learning motivation of students at SMP Negeri 1 Bojonegoro, (2) any indicators giving of gift and punishment.
\end{abstract}

Keywords: Reward and punishment, learning motivation, students

(1) Licensees may copy, distribute, display and perform the work and make derivative works and remixes based on it only if they give the author or licensor the credits (attribution) in the manner specified by these. Licensees may copy, distribute, display, and perform the work and make derivative works and remixes based on it only for non-commercial purposes.

\section{PENDAHULUAN}

Pendidikan dan manusia memang tidak dapat dipisahkan dalam menjalani kehidupan, baik keluarga, masyarakat maupun bangsa dan negara, karena pendidikan memiliki peranan penting dalam meningkatkan kualitas sumber daya manusia dan upaya mewujudkan cita-cita bangsa Indonesia. Pendidikan merupakan faktor utama dalam pembentukan pribadi manusia. Hampir semua orang dikenai pendidikan dan melaksanakan pendidikan (Navil Alfarisi Abbas, Iskandar Syah, 2017)

Penghargaan adalah alat untuk mendidik anak-anak supaya anak senang karena perbuatan atau pekerjaannya mendapat penghargaan (Purwanto, 2011). Penghargaan merupakan alat pendidikan yang mudah dilaksanakan dan sangat menyenangkan bagi para siswa. Untuk itu penghargaan dalam satu proses pendidikan sangat dibutuhkan kebenarannya demi meningkatkan motivasi belajar siswa. Dalam teori pembelajaran dikenal dengan istilah Law of Effect perilaku yang bersifat menyenangkan cenderung untuk diulang atau dipertahankan, sedangkan perilaku yang menimbulkan efek tidak menyenangkan cenderung untuk ditinggalkan atau tidak diulang (Sriyanti, 2009)

Efek yang tidak menyenangkan dapat disebut sebagai hukuman sedangkan efek yang menyenangkan dirasakan sebagai penghargaan. (Kompri, 2015) hukuman itu sendiri adalah sebuah cara untuk mengarahkan sebuah tingkah laku agar sesuai dengan tingkah laku yang berlaku secara umum. Dalam hal ini, hukuman diberikan ketika sebuah tingkah laku yang tidak diharapkan ditampilkan oleh orang yang bersangkutan tidak memberikan respons atau tidak menampilkan sebuah tingkah laku yang diharapkan. Berdasarkan uraian di atas, dapat disimpulkan bahwa hukuman diartikan sebagai hukum atau sanksi. Hukuman biasanya dilakukan ketika apa yang menjadi target tertentu tidak tercapai, atau ada perilaku anak yang tidak sesuai dengan norma-norma yang diyakini oleh sekolah tersebut. Jika penghargaan merupakan bentuk reinforcement yang positif, maka punishment sebagai bentuk reinforcement yang negatif, tetapi kalau diberikan secara tepat dan bijak bisa menjadi alat motivasi. 
Motivasi menjadi penting bagi keberhasilan siswa, karena motivasi dapat menjadi daya dorong seseorang untuk melakukan sikap belajar positif. salah satu faktor yang dapat diberikan kepada siswa yang lemah dalam motivasinya adalah dengan melalui pemberian hadiah dan hukuman yang tepat bagi siswa tersebut. Sehingga melalui pemberian hadiah dan hukuman tersebut, semangat dan motivasi siswa dalam belajar dapat meningkat. Motivasi siswa dapat timbul dari dalam diri individu (motivasi intrinsik) dan dapat timbul dari luar diri siswa (motivasi ekstrinsik) (Aziz, 2017) (Sardiman, 2008) dalam belajar diperlukan adanya motivasi. Hasil belajar akan menjadi optimal kalau ada motivasi. Makin tepat motivasi yang diberikan, akan makin berhasil pula pelajaran itu. Jadi dapat dikatakan motivasi akan senantiasa menetukan intensitas usaha belajar bagi para siswa sehingga hasil belajar siswa akan semakin meningkat. Penghargaan dan hukuman sangat penting dalam memotivasi siswa, karena melalui penghargaan dan hukuman siswa akan menjadi lebih percaya diri dan bertanggung jawab dengan tugas yang diberikan. Penghargaan dan hukuman adalah dua kata yang saling bertolak belakang akan tetapi, kedua hal tersebut saling berkaitan, keduanya memacu siswa untuk meningkatkan kualitas kerja. Penghargaan dan hukuman sangat erat hubungannya dengan pemberian motivasi siswa (Febrianti, 2014). Di samping hal di atas pembiasaan tingkah laku berkarakter seperti yang dilakukan di sekolah, asrama, dan/atau pesantren menjadi faktor pendorong memperkuat pendidikan karakter (Hadiyanto, 2016).

\section{METODE}

Penulisan artikel ini menggunakan metode deskriptif kualitatif untuk memperoleh data secara deskriptif alamiah di lapangan yang dijadikan obyek atau latar penelitian. Peneliti melakukan kegiatan wawancara mendalam dengan ketua organisasi kader penegak disiplin sebagai informan. Selanjutnya peneliti melakukan pengamatan langsung di SMP Negeri 1 Bojonegoro untuk melihat bagaimana penerapan pendidikan karakter di sekolah yang didapatkan setelah pelaksanaan kegiatan MOS. Metode seperti ini disebut dengan rancangan penelitian kualitatif dengan pendekatan studi kasus (Moleong, 2010). Kemudian guna memperoleh informasi yang cukup dan mendalam peneliti melakukan studi dokumentasi dengan mengecek dokumen sekolah seperti profil SMP Negeri 1 Bojonegoro. Peneliti melihat dan mengecek secara langsung dokumen-dokumen berupa arsip kegiatan dalam pemberian reward dan punishment dalam bentuk buku pelanggaran dan buku-buku peserta didik yang meraih prestasi dan mendapatkan penghargaan dari SMP N 1 Bojonegoro, dokumentasi kegiatan berupa foto-foto, dan dokumen lain yang berkaitan dengan fokus penelitian. Setelah itu peneliti menyusun catatan lapangan dan melaporkan temuan dalam sajian artikel penelitian.

\section{TEORI DAN PEMBAHASAN}

Dari penelitian yang dilakukan peneliti di lapangan hasilnya adalah sebagai berikut: (1) fenomena tentang penguatan karakter melalui penerapan penghargaan dan hukuman; (2) membahas indikator peserta didik yang mendapatkan penghargaan dan hukuman. Pemberian penghargaan dan hukuman sangat berpengaruh terhadap motivasi belajar siswa seperti siswa akan semakin giat belajar demi mendapatkan nilai yang terbaik, bersaing antar siswa untuk berprestasi, dan tentunya yang tidak kalah penting yaitu supaya mendapatkan suatu penghargaan dari sekolah. Hukuman pada seluruh peserta didik SMP Negeri 1 Bojonegoro yang berperilaku tidak sesuai dengan peraturan atau tata tertib yang terdapat di SMP Negeri 1 Bojonegoro akan dilaporkan dalam bentuk buku pelanggaran, dan di catat oleh tim khusus yang telah dibentuk oleh sekolah yaitu bernama Kader Penegak Disiplin (KDR). Dimana rekaman dari keseluruhan tingkah laku peserta didik di sekolah akan disampaikan kepada orang tua setiap satu bulan sekali.

Indikator peserta didik yang mendapatkan hukuman tentunya peserta didik yang kurang menaati peraturan sekolah, seperti terlambat, kurang baik dalam menggunakan sosial media, tidak berpakaian yang sesuai dengan ketentuan dari sekolah, membawa handphone, memutar musik yang terlalu keras lewat DVD player, dan berpacaran di sekolah, 
itu merupakan beberapa contoh pelanggaran yang sering di langgar oleh peserta didik SMP Negeri 1 Bojonegoro. Sedangkan kalau kriteria untuk peserta didik yang mendapatkan penghargaan dari sekolah seperti selalu tepat waktu saat datang ke sekolah, berpakaian rapi, bertutur kata yang sopan dan santun, selalu menggunakan atribut yang lengkap dari sekolah, tidak pernah melanggar satu pun dari pelanggaran sekolah, dan dapat mengharumkan nama baik sekolah baik dalam lingkup kabupaten, propinsi, nasional, dan bahkan internasional.

\section{Pengaruh Pemberian Reward dan Punishment terhadap Motivasi Belajar Peserta Didik}

Pengaruh penghargaan dan hukuman yaitu sangat berpengaruh terhadap motivasi belajar peserta didik, dikarenakan jika peserta didik itu belajarnya rajin, maka ia akan mendapatkan sebuah prestasi, prestasi tersebut akan berdampak baik kepada peserta didik, yaitu peserta didik mendapatkan penghargaan dari sekolah, Penghargaan tersebut akan selalu meningkatkan motivasi siswa untuk selalu belajar. Sama halnya seperti teori behavioristik yaitu teori yang mempelajari perilaku manusia. Perspektif behavioral berfokus pada peran dari belajar dalam menjelaskan tingkah laku manusia dan terjadi melalui rangsangan berdasarkan (stimulus) yang menimbulkan hubungan perilaku reaktif (respons). Seseorang memperbaiki atau menghentikan suatu tingkah laku, karena mungkin tingkah laku tersebut telah diberi ataupun belum diberi hadiah (Fahyuni, Eni, F., 2016). Karena semua tingkah laku yang baik bermanfaat ataupun yang merusak, merupakan tingkah laku yang dipelajari.

\section{Indikator Peserta Didik Mendapatkan Reward dan Punishment}

Peserta didik yang biasanya mendapatkan penghargaan ataupun hukuman tentunya ada beberapa indikator yaitu: peserta didik yang tidak pernah terlambat datang ke sekolah, peserta didik yang dapat menggunakan sosial media secara terkontrol dan dapat menyaring informasi dari sosial media, peserta didik selalu berpakaian seragam sesuai dengan ketentuan tata tertib atau kode etik yang berlaku di sekolah menggunakan seragam yang rapi dan beratribut(Imron, 2012). Kode etik adalah aturan dan ketentuan yang telah disepakati dan diterima oleh warga masyarakat yang dijadikan panduan dalam bertingkah laku (Imron, 2012). Seragam sekolah merupakan alat untuk membuat kerapihan, kedisiplinan dan keteraturan siswa dalam melaksanakan pendidikan. peraturan pada dasarnya bertujuan untuk menjadikan generasi penerus yang berdisiplin dan berprestasi (Trisnawan, Titis, 2017).

Jika peserta didik mentaati sebagian peraturan dari sekolah tersebut, maka peserta didik akan mendapat pujian dari bapak dan ibu guru supaya merasa senang karena apa yang dilakukan mendapatkan penghargaan (Purwanto, 2011), seperti halnya jika peserta didik datang terlambat ke sekolah, maka bapak dan ibu guru akan memberikan sanksi kepada peserta didik sebagai akibat datang ke sekolah terlambat dengan cara menegur peserta didik dengan memberikan hukuman berupa lari $3 \mathrm{x}$ keliling lapangan atau membersihkan daundaun di sekitar lapangan (Imron, 2012). Kalau untuk peserta didik yang tidak berpakaian rapi, maka bapak atau ibu guru akan menyuruh peserta didik tersebut ke toilet terlebih dahulu untuk membersihkan atau merapikan pakaian seragamnya.

Peserta didik yang kurang baik dalam penggunaan sosial media, tim dari kader penegak disiplin langsung memanggil peserta didik tersebut dan memberitahukan bahwa perilaku yang dia katakan di sosial media yaitu kurang pantas, jika peserta didik tersebut masih mengulangi perbuatannya di sosial media maka tim dari kader penegak disiplin tidak segan-segan untuk langsung mengantarkan peserta didik tersebut ke bapak dan ibu guru supaya dapat ditindak lanjuti dalam hal pemberian poin. Sebelumnya tim dari kader penegak disiplin telah mendata keseluruhan sosial media dari setiap peserta didik di SMP Negeri 1 Bojonegoro. Oleh karena itu, tim dari kader penegak disiplin lebih gampang untuk memantau setiap gerakgerik siswa baik di lingkungan sekolah maupun di lingkungan sosial media. Apabila terdapat peserta didik yang melanggar pasal dalam buku tata tertib yang parah seperti 
pacaran di sekolah, merokok akan diberikan poin 45 dari sekolah.

Berbeda halnya dengan peserta didik yang dapat memenangkan perlombaan dalam tingkat kabupaten, propinsi, nasional, atau bahkan internasional maka akan diberikan reward atau penghargaan dari sekolah bisa dalam bentuk pemberian sertifikat atau hanya merekap nama peserta didik dan prestasi apa yang telah ia raih. Kalau hanya tingkat sekolah atau tingkat kecamatan maka akan di rekap saja di dalam buku sekolah, kalau sudah tingkat kabupaten sampai dengan tingkat internasional akan diberikan sertifikat penghargaan dari sekolah. Jadi kesimpulannya, jika peserta didik mendapat prestasi tingkat kabupaten sampai tingkat internasional, maka peserta didik tersebut akan diberikan sebuah penghargaan berupa sertifikat. Kalau peserta didik melangggar tata tertib dan peraturan sekolah, peserta didik dominan hanya diberikan skor dan poin. Poin tersebut juga dapat menyadarkan peserta didik akan kesalahannya dan jera untuk tidak mengulanginya lagi.

Dampak positif penjeraan siswa, agar siswa kapok atau tidak mengulangi pelanggaran peraturan sekolah yaitu untuk: 1) Menciptakan kedisiplinan siswa agar anak didik belajar dengan baik; 2) Melindungi siswa dari perbuatan yang tidak wajar; 3) Menakuti siswa, agar meninggalkan perbuatannya yang melanggar itu (Ahmadi \& Nur, 2001). Dengan adanya sikap disiplin pada diri siswa, siswa akan tahu dan dapat membedakan hal-hal apa yang seharusnya dilakukan, yang wajib dilakukan, yang boleh dilakukan, yang sepatutnya dilakukan. Apabila ia berbuat hal yang menyimpang, ada perasaan "aneh", merasa malu. Disiplin yang mantap pada hakikatnya akan tumbuh dan terpancar dari hasil kesadaran pada diri siswa itu sendiri, tetapi juga ada yang belum jera jika hanya diberikan poin atau skor saya karena menganggap skor atau poin yang diberikan masih sedikit, padahal kalau sudah mendapatkan poin 50 ke atas maka akan selalu diperingatkan untuk tidak melakukan berbagai pelanggaran, jika telah mencapai 95 ke atas sampai 100 peserta didik tersebut langsung secara otomatis dikeluarkan dari sekolah (Soemarno, 1998).

\section{KESIMPULAN}

Dari hasil pembahasan simpulan dari penelitian ini adalah: (1) penghargaan dan hukuman sebagai bentuk penguatan karakter peserta didik karena dengan adanya penghargaan, peserta didik selalu ingin menjadi lebih baik setiap harinya supaya dapat dipuji oleh guru-guru atau dapat meningkatkan peserta didik untuk berprestasi. Sedangkan hukuman akan membuat peserta didik jera dan tidak akan mengulangi perilaku yang melanggar tata tertib sekolah; (2) indikator pemberian penghargaan dan hukuman yaitu jika peserta didik taat dan mematuhi segala tata tertib yang telah disepakati di sekolah, peserta didik dapat mengharumkan nama sekolah maka sekolah juga akan memberikan umpan balik yang positif kepada peserta didik, begitu sebaliknya jika peserta didik susah diatur, berperilaku semaunya sendiri maka sekolah juga tidak segan-segan untuk memperingatkan dan memanggil peserta didik atau bahkan bisa memberi nya poin, jika poin sudah melampaui batas kewajaran maka orang tua peserta didik dipanggil ke sekolah.

Dari simpulan diatas, saran penelitian ini ditujukan kepada: (1) Kepala sekolah diharapkan supaya mempertahankan penguatan karakter berupa diadakannya program penghargaan dan hukuman,(2) Peserta didik diharapkan selalu meningkatkan perilaku positifnya untuk selalu mengharumkan nama sekolah dari perilaku positif maka peserta didik juga pastinya akan mendapatkan sebuah penghargaan dari sekolah; (3) Orang tua peserta didik diharapkan selalu memperingatkan anak-anaknya supaya selalu berprestasi untuk mendapatkan sebuah hadiah atau penghargaan dari sekolah.

\section{REFERENSI}

Ahmadi, A., \& Nur, U. (2001). Psikologi Sosial. PT Rineka Cipta.

Aziz, A. L. (2017). Pengaruh Motivasi Intrinsik dan Motivvasi Ekstrinsik terhadap Prestasi Belajar Ekonomi Bisnis Kelas X Peserta Didik Kelas X di SMKN 4. Universitas Negeri Makassar.

Fahyuni, Eni, F., I. (2016). Psikologi Belajar \& Mengajar. Nizamia Learning Center.

Febrianti. (2014). Pengaruh Reward dan Punishment terhadap Motivasi Kerja serta 
Dampaknya terhadap Kinerja. Jurnal Administrasi Bisnis, 12(1).

Hadiyanto. (2016). Teori dan Pengembangan Iklim Kelas dan Iklim Sekolah. Kencana. http://repository.unp.ac.id/id/eprint/12920

Imron, A. (2012). Manajemen Peserta Didik Berbasis Sekolah. Bumi Aksara.

Kompri. (2015). Motivasi Pembelajaran Perspektif Guru dan Siswa. Remaja Rosdakarya.

Moleong, L. J. (2010). Metodologi Penelitian Kualitatif Edisi Revisi. Remaja Rosdakarya.

Navil Alfarisi Abbas, Iskandar Syah, M. B. (2017). Pengaruh Metode Reward dan Punishment terhadap Motivasi Belajar Siswa Kelas XI IPS. PESAGI (Jurnal Pendidikan Dan Penelitian Sejarah), 6(6).
Purwanto. (2011). Evaluasi Hasil Belajar. Pustaka Belajar.

Sardiman. (2008). Interaksi dan Motivasi Belajar Mengajar. PT Raja Grafindo Persada.

Soemarno, D. (1998). Pedoman Pelaksanaan Disiplin Nasional dan Tata Tertib Sekolah. CV. Mini Jaya Abadi.

Sriyanti, I. (2009). Penerapan Model Pembelajaran Interaktif Berbasis Konsep. Jurnal Pengajaran Fisika Sekolah Menengah, 1(1), 23-26.

Trisnawan, Titis, and S. (2017). Pendidikan Karakter Disiplin. Universitas Muhammadiyah Purwokerto. 